\title{
Targeting cannabinoid receptor activation and BACE-1 activity counteracts TgAPP mice memory impairment and Alzheimer's disease lymphoblasts alterations
}

\author{
Emilio Nuñez-Borque ${ }^{1 *}$, Pedro González-Naranjo ${ }^{2 *}$, Fernando Bartolomé $^{3,4}$, \\ Carolina Alquézar $^{1 \dagger}$, Alejandro Reinares ${ }^{1}$, Concepción Pérez ${ }^{2}$, Maria L. Ceballos ${ }^{4,5}$, \\ Juan A. Páez ${ }^{2}$, Nuria E. Campillo ${ }^{1}$, and Ángeles Martín-Requero ${ }^{1,4}$ \\ ${ }^{1}$ Centro de Investigaciones Biológicas (CSIC) Madrid, ${ }^{2}$ Instituto de Química Médica \\ (CSIC), ${ }^{3}$ Neurodegenerative Disorders group, Instituto de Investigación Hospital 12 de \\ Octubre. ${ }^{4}$ Centro de Investigación Biomédica en Red sobre Enfermedades \\ Neurodegenerativas (CIBERNED), Madrid, ${ }^{5}$ Insituto Cajal (CSIC), Madrid.
}

*Equal contribution

$\uparrow$ Present address: Department of Neurology, Memory and Aging Center, University of

California, Box 1207, San Francisco, CA, 94158, USA.

Running Title: multitarget cannabinoid agonists for AD treatment

Key words: Alzheimer's disease, cannabinoids, lymphoblasts, cell proliferation, cell survival, TgAPP mice, memory.

Address for correspondence:

Dr. Ángeles Martín-Requero, Dr. Nuria E. Campillo

Centro de Investigaciones Biológicas (CSIC)

Ramiro de Maeztu 9, 28040 Madrid, SPAIN

Phone: 34-91-837-3112

Email: amrequero@cib.csic.es, nuria.campillo@cscic.es

AM-R ORCID: 0000-0002-3416-9440

NEC ORCID: 0000-0002-9948-2665 


\section{ABSTRACT}

Alzheimer's disease (AD), the leading cause of dementia in the elderly, is a neurodegenerative disorder marked by progressive impairment of cognitive ability. Patients with AD display neuropathological lesions including senile plaques, neurofibrillary tangles, and neuronal loss. There are no disease-modifying drugs currently available. With the number of affected individuals increasing dramatically throughout the world, there is obvious urgent need for effective treatment strategy for AD. The multifactorial nature of $\mathrm{AD}$ encouraged the development of multifunctional compounds, able to interact with several putative targets. Here, we have evaluated the effects of two in-house designed cannabinoid receptors (CB) agonists showing inhibitory actions on $\beta$ secretase-1 (BACE-1) (NP137) and BACE-1/butyrylcholinesterase (BuChE) (NP148), on cellular models of $\mathrm{AD}$, including immortalized lymphocytes from late-onset $\mathrm{AD}$ patients. Furthermore, the performance of TgAPP mice in a spatial navigation task was investigated following chronic administration of NP137 and NP148. We report here that NP137 and NP148 showed neuroprotective effects in amyloid $\beta$-treated primary cortical neurons, and NP137 in particular rescued the cognitive deficit of TgAPP mice. The latter compound was able to blunt the abnormal cell response to serum addition or withdrawal of lymphoblasts derived from AD patients. It is suggested that NP137 could be a good drug candidate for future treatment of $\mathrm{AD}$. 


\section{Introduction}

Alzheimer's disease (AD) is the most common form of dementia in the elderly affecting around 30 million people worldwide. Neuropathologically, AD is characterized by the extracellular accumulation of amyloid- $\beta$ (A $\beta)$ plaques and intracellular neurofibrillary tangles (NFTs) of hyperphosphorylated tau protein, associated with neuronal cell death. Nevertheless, the cause of neuronal death remains elusive. AD is a multifactorial disease involving different etiopathogenic mechanisms, including APP pathogenic cleavage, neurotransmitter dyshomeostasis, protein misfolding, mitochondrial dysfunction, oxidative stress, and neuronal abortive cell cycle re-entry among others [1,2].

Currently available treatments for $\mathrm{AD}$ are symptomatic and do not prevent or slow the progression of the disease [3]. Thus disease-modifying therapy is urgently needed to treat the growing number of affected individuals, and a major goal of research of AD therapeutics. Considering the multifactorial nature of $\mathrm{AD}$, a great effort has been devoted to develop multitarget compounds able to interfere with several of the proposed pathogenic causes. Our group has been engaged during the last decade, in the development of multitarget drugs for AD treatment [4-6]. Recently, we have reported the synthesis of a family of new indazolylketones derivatives with a multitarget profile, showing activity at cannabinoid receptors (CBRs) as agonists, inhibitors of butyrylcholinesterase (BuChE) and $\beta$-secretase-1 (BACE-1) [5]. Further biological studies in cellular and in vivo models of $\mathrm{AD}$ with two of the most interesting multitarget compounds are described in this work. Specific, NP137 a mixed cannabinoid agonist and BACE-1 inhibitor and NP148 a cannabinoid agonist and BACE-1/BuChE inhibitor have been studied.

Cannabinoids exert a wide spectrum of central and peripheral effects by activating specific cannabinoid receptors $\mathrm{CB} 1$ and $\mathrm{CB} 2$. $\mathrm{CB} 1$ receptors are expressed mainly in 
nervous system [7], while CB2 receptors are more abundant in cells and organs of the immune system [8], although some reports indicate that CB2 receptors are also expressed in brain, not only in glial cells but in neurons as well $[9,10]$. The interest in cannabinoids application in $\mathrm{AD}$ comes from the observation that the endocannabinoid system is dramatically altered in $\mathrm{AD}$ brain [11]. Indeed, a decrease in $\mathrm{CB} 1$ receptor protein has been reported along a reduction in cannabinoid agonist G-protein coupling, increased CB2 immunoreactivity in senile plaques, decreased anandamide levels and of the major endocannabinoid degrading enzymes [12-15]. More important is the fact that cannabinoids exert neuroprotective effects in different experimental conditions of acute brain injury, such as excitotoxicity, glucose deprivation and hypoxia, or cerebral ischemia $[16,17]$. Morever, cannabinoid agonists had been shown to reduce A $\beta$-induced memory impairment, while reducing the neuroinflammatory response and brain $\mathrm{A} \beta$ levels in $\mathrm{AD}$ animal models [18-20,12].

BACE-1 is a transmembrane aspartic protease implicated in the generation of $A \beta$ peptides through the cleavage of APP. Moreover, BACE-1 is increased in the brain cortex of most patients with sporadic AD [21,22] and in AD transgenic mice [23,24]. These evidences make BACE-1 an attractive therapeutic target in AD.

BuChE together with $\mathrm{AChE}$ belong to cholinesterase (ChEs) family of enzymes and play a role in acetylcholine regulation and in the cholinergic signaling. BuChE, in a different way to AChE, is non-substrate specific and is distributed throughout the body [25]. Two decades ago, the relevance of $\mathrm{BuChE}$ in human brain and specifically in $\mathrm{AD}$ was underestimated owing to its low expression [26]. However, during the last years, several studies have shown the importance of BuChE within the nervous system to be pivotal in the late stages of AD [27]. AChE knockouts establish central cholinergic pathways and can use BuChE to hydrolyze acetylcholine [28,29]. 
Given the complex nature of the neuropathology of $\mathrm{AD}$ we considered that targeting several molecular pathways at the same time would be interesting. Therefore, in this work we have analyzed the effects of two multitarget compounds, $\mathrm{CB}$ agonists and inhibitor of BACE-1 (NP137) or BACE-1/BuChE (NP148), on neuronal cells in vitro and murine model of AD in vivo. Furthermore, the effects of NP137 have been evaluated in peripheral cells from late-onset $\mathrm{AD}$ patients.

We show here that both multitarget CB agonists NP137 and NP148 showed neuroprotective effects against $A \beta$-induced cell death in primary rat cortical neurons. Furthermore, it is reported that following chronic administration of NP137, but not NP148, improved the performance of TgAPP mice in a spatial navigation task, without altering motor activity. NP137 was able to normalized the response of lymphoblasts derived from $\mathrm{AD}$ patients to serum stimulation or withdrawal. 


\section{Materials and Methods}

All components for cell culture were obtained from Invitrogen (Carlsbad, CA, USA). PVDF (polyvinylidene difluoride) membranes for Western blots were purchased from Bio-Rad (Richmond, CA, USA). The enhanced chemiluminiscence (ECL) system was from Amersham (Uppsala, Sweden). All other reagents were of molecular grade. Antibodies against $\beta$-actin (sc-81178), pRb (sc-500), p27 (sc-528), were obtained from Santa Cruz Biotechnologies (Santa Cruz, CA, USA) and anti-Lamin B1 was purchased from Calbiochem (Billerica, MA, USA). Rabbit polyclonal antibodies (pAbs) against human phospho-Akt (Ser473), phospho-ERK1/2, anti-total Akt were obtained from Cell Signaling (Beverly, MA, USA).

\section{Compound preparation}

NP137 (4-methoxybenzyl)(3-(3-(piperidinopropoxy)indazol-1-yl)ketone) and NP148 ((2-benzyloxyphenyl)(3-(3-piperidinopropoxy)indazol-1-yl)ketone) were synthesized as previously described [4,5]. Chemical details of NP137 and NP148 [5] together with effective permeability values that predict its ability to cross the blood brain barrier (BBB) are provided in Table 1.

The compounds were dissolved in 100\% dimethyl sulfoxide (DMSO) as a $10 \mathrm{mM}$ stock and diluted with phosphate-buffered saline (PBS; Invitrogen) to final concentrations. $\mathrm{A} \beta_{42}$ powder (AnaSpec, Inc., San Jose, CA), was dissolved in acetic acid (0.1M) obtaining a $2 \mu \mathrm{g} / \mu \mathrm{L}$ stock. Then $\mathrm{A} \beta_{42}$ was oligomerized in no phenol red DMEM for $24 \mathrm{~h}$ at $4{ }^{\circ} \mathrm{C}$. The final concentration in the rat primary cortical neuron cultures was $5 \mu \mathrm{M}$. All dilutions of stock were prepared fresh before addition to the culture medium.

\section{Primary cortical neuronal cultures}

Pregnant Wistar rats (3-5 months) were obtained from the inbred colony of the Research 
Institute, Hospital Doce de Octubre, Madrid, Spain. Primary cortical neuronal cultures were prepared from rat embryos (E15-16) according to methods described previously [30,31]. $3 \times 10^{4}$ cells per well were plated in pre-treated poly-D-lysine-coated 96-well plates. Cells were maintained at $37^{\circ} \mathrm{C}$ in a $5 \% \mathrm{CO}_{2}$ humidified atmosphere in Neurobasal A medium (Gibco) containing $2 \mathrm{mM}$ L-glutamine, and 10\% B27 Supplement (Invitrogen). Nine days after cell culture preparation, cortical neurons were treated with $5 \mu \mathrm{M} \mathrm{A} \beta_{42}$ for $24 \mathrm{~h}$ and pre-treated or not for $1 \mathrm{~h}$ with increasing concentrations of NP137. After treatment, cultures were processed for cell viability assay using 3-(4,5dimethylthiazol-2-yl)-2,5-diphenyltetrazolium bromide (MTT) as previously described [32]. All animals were handled and cared for Council Directive 2010/63/UE of September 22, 2010.

\section{Animals and treatments}

Male TgAPP (line 2576) harboring two Swedish mutations of 12 months of age at the start of the experiments were used. Controls consisted of littermate wild type mice (WT). Animals were group-housed (4-5 animals per cage) under standard conditions (12:12 h light/dark cycle) with food chow and water accessed ad libitum. All procedures were performed in agreement with the ethical regulations on the use and welfare of experimental animals of the EU and the Spanish Ministry of Agriculture, and the bioethical committee of the CSIC approved them.

Oral administration was selected since it is highly suitable for long-term treatment and its translation into the Clinic. The compounds under study were administered in the drinking water at a dose of $1 \mathrm{mg} / \mathrm{kg} /$ day, starting at 12 months of age, for 3.5 months. This dose was selected considering our previous studies with cannabinoid compounds $[19,20]$ and their in vitro potency. Compounds were first dissolved in $1 \mathrm{ml}$ of DMSO, and thereafter 
diluted in water. The volume drank by the mice was monitored every other day and the compound concentration was adjusted to the weight of the animals (assessed weekly) and the fluid drank. All animals had a similar body weight both at the start and at the end of the experiments (not shown). The amount of water drank was similar across the different groups discarding any reinforcing effects of the drugs (not shown).

\section{Behavioral tests}

All the procedures were performed in isolated rooms at the same time of the day to avoid circadian effects (from $9.00 \mathrm{~h}$ to $14.00 \mathrm{~h}$ ).

Motor activity was monitored in activity cages (Digiscan; AccuScan Instruments, Columbus, OH, USA) for $10 \mathrm{~min}$. The apparatus consisted of several independent open fields of $20 \mathrm{~cm} \times 20 \mathrm{~cm}$, with photobeam sensors. Horizontal activity, measured as distance travelled $(\mathrm{cm})$, and vertical activity (number of rears) over 10 min were recorded.

Spatial learning and memory were assessed by means of the water maze as described in reference [12]. In brief, the mice were trained to find a hidden platform in a pool of 100 $\mathrm{cm}$ diameter, over 5 days. Each day the animals were submitted to 4 trials of $60 \mathrm{sec}$ duration, at least $30 \mathrm{~min}$ apart, and the latency to reach the platform was recorded. Mice failing to reach the platform were gently placed on it and removed after $15 \mathrm{sec}$. On the sixth day the platform was removed and the mice were allowed to swim for $90 \mathrm{sec}$. The time spent in each quadrant of the pool was recorded. The behavior of the animals was acquired with a video camera and analyzed (Noldus Technology, The Netherlands).

\section{Ex vivo enzymatic assays}

Mice were killed by decapitation, the brain was dissected on a cold plate and samples stored at $-80^{\circ} \mathrm{C}$ until assayed. Cerebral cortical samples were homogenized in 20 volumes of Tris $\mathrm{HCl} 50 \mathrm{mM}$, pH 7.7, with a Polytron. Samples were centrifuged at 
3,000 $\mathrm{g}$ and the supernatants were used to assess $\mathrm{AChE}$ and $\mathrm{BuChE}$ activities. In brief, $20 \mu \mathrm{l}$ of supernatant was assayed in a final volume of $200 \mu 1$, in $100 \mathrm{mM}$ phosphate buffer ( $\mathrm{pH}$ 8) containing either acetylthiocholine or butirylthiocholine $(0.4$ $\mathrm{mM}$ ) as substrates of the reaction, and 5,5-dithio-bis-(2-nitrobenzoic acid) (DTNB, Ellman's reagent, $0.2 \mathrm{mM}$ ), and the absorbance was read at $412 \mathrm{~nm}$, after $30 \mathrm{~min}$ incubation at $30^{\circ} \mathrm{C}$. Samples were assayed in triplicate and the results are expressed as $\mathrm{pmol} / \mathrm{min} \mathrm{x} \mathrm{mg}$ of tissue (wet weight). While the activity of AChE was detected in all the samples, BuChE activity was beyond the level of detection.

\section{Cell lines}

A summary of demographic characteristics of all subjects enrolled in this study is reported in Table 2. A total of 20 patients were diagnosed in the department of Neurology of the University Hospital Doce de Octubre (Madrid, Spain) of probable Alzheimer's disease according to NINCDS-ADRDA (National Institute of Neurological and Communicative Diseases and Stroke-Alzheimer's Disease and Related Disorders Association) criteria. Establishment of lymphoblastic cell lines and culture was performed in our laboratory as previously described [33]. All study protocols were approved by the Hospital Doce de Octubre and the Spanish Council of Higher Research Institutional Review Board and are in accordance with National and European Union Guidelines. In all cases, peripheral blood samples were taken after written informed consent of the patients or their relatives.

\section{Determination of cell proliferation, cell viability and cell cycle}

Cell proliferation was determined by total cell counting, using a $\mathrm{TC} 10^{\mathrm{TM}}$ Automated Cell Counter, Bio-Rad Laboratories, S.A. (Madrid, Spain). EBV-immortalized lymphocytes from control and $\mathrm{AD}$ patients were seeded at an initial cell concentration of $1 \times 10^{6}$ cells $\mathrm{x} \mathrm{mL}^{-1}$ and enumerated everyday thereafter. Cells failing to exclude Trypan blue were considered nonviable. Cell viability was determined by the MTT assay. Cell survival was 
estimated as the percentage of the value of untreated controls. Morphological evaluation was performed using an inverted phase contrast Olympus microscope IX-50. Images were taken with a CCD camera Hamamatsu 9100-02. For cell cycle analysis, cells were fixed in $75 \%$ ethanol for 1 hour at room temperature. Subsequent centrifugation of the samples was followed by incubation of cells PBS containing $1 \mu \mathrm{g} / \mathrm{mL}$ of RNase at room temperature for 20 minutes and staining with propidium iodide (PI; $25 \mu \mathrm{g} / \mathrm{mL}$ ). Cells were analyzed in an EPICS-XL cytofluorimeter (Coulter Científica, Móstoles, Spain). Estimates of cell cycle phase distributions were obtained by computer analysis of DNA content distributions.

\section{Immunoblotting analysis}

Cells were collected by centrifugation, washed with PBS and total protein extracts were obtained by lysing them as previously described [34]. To separate the cytosolic and nuclear fractions, cells were harvested, washed in PBS and then lysed in ice-cold hypotonic buffer as previously described [35]. After extraction on ice for $15 \mathrm{~min}, 0.5 \%$ Nonidet P-40 was added and the lysed cells were centrifuged at 4,000 rpm for $10 \mathrm{~min}$. Supernatants containing cytosolic proteins were separated and pellets were resuspended in hypertonic buffer to lysate the nucleus. The protein content of the extracts was determined by the Pierce BCA Protein Assay kit (Thermo Scientific). Equal amounts of proteins were resolved by SDS-polyacrylamide gel electrophoresis. The proteins were then transferred to polyvinylidene fluoride (PVDF) membranes for immunodetection. Primary antibodies were used at the following concentrations: anti-pRb (1:1000); antip27 (1:500); anti-phospho-Akt (Ser473) (1:1000); anti-Akt (1:1000); anti- $\beta$-actin (1:500); anti-phospho-ERK1/2 (Thr286) (1:1000); anti-ERK1/2 (1:500). The relative band intensities were quantified using Image Studio Lite software (LI-COR Biotechnology). 


\section{Statistical analysis}

Graphical representation and statistical analyses were performed with Graph Pad Prism 8 (La Jolla, CA, USA). All the statistical data are presented as mean \pm standard error of the mean (SEM). Normality was checked with the Shapiro-Wilk test. Parametric tests were therefore used in the statistical analysis. Statistical significance was estimated by both one-way and two-way analysis of variance (ANOVA) followed by the Fisher's test for multiple comparisons. In the water maze experiments repeated measures ANOVA was used, followed by one-way ANOVA at each time point. A value of $p<0.05$ was considered significant. 


\section{Results}

\section{Neuroprotective effects of NP137 and NP148 on $\beta$-amyloid-induced cell death in rat primary cortical neuronal cultures.}

We first evaluated the potential neuroprotective effects of multitarget CB agonist and BACE-1 inhibitor, (NP137) and NP148, a CB agonist with a profile of BACE-1 and BuChE inhibitor in rat primary cortical neuronal cultures. For these experiments, rat primary cortical neurons were preincubated in the absence or in the presence of increasing concentrations of NP137 or NP148 and then exposed for $24 \mathrm{~h}$ to A $\beta$. As shown in Fig. 1, cortical neurons' viability was markedly decreased after the cell was exposed to $A \beta$ as determined by MTT, while pretreated with NP137 or NP148 (2.5 and $5 \mu \mathrm{M})$ the A $\beta$ induced cell death was significantly attenuated.

\section{NP137, but not NP148, counteracts cognitive deficits in TgAPP mice}

We next seek to evaluate the effects of NP137 and NP148 in a murine model of AD. To this end, mice received prolonged oral administration of compounds ( $1 \mathrm{mg} / \mathrm{kg} / \mathrm{day}$ po).

As shown in Fig. 2 (A-B) TgAPP mice showed learning deficits in the water maze as compared to WT animals receiving vehicle. Indeed, WT mice learned the task over the five training days, as judged by the decrease in latency time to reach the platform, while TgAPP mice needed more time. Prolonged oral administration of NP137 delayed the learning of WT animals, and there was a significant difference in the time to reach the

platform at day 3 and day 4 compared to WT mice receiving vehicle, although at day 5 all WT mice, regardless their treatment, had the same latency (Fig. 2A). In contrast, longterm administration of NP137 to TgAPP mice completely restored their cognitive abilities, and their latencies to reach the platform were almost identical to WT vehicle treated mice. NP148 continuous administration neither altered the learning of WT nor 
modified the learning deficits of TgAPP mice. In fact, the animals on NP148 treatment improved at day 2 in comparison to day 1 performance, but the latency was maintained until day 5. Next, we examined the time spent in each quadrant of the pool on day 6 , following the training period. There was a significant decrease in the time TgAPP mice spent in the platform quadrant compared to WT vehicle treated animals. This decrease was fully reversed but continuous administration of NP137, but unaffected by NP148 treatment. In summary, NP137 was able to restore the learning and memory deficits shown by TgAPP mice.

Given that the water maze relies in locomotor activity it was necessary to assess any effects of the new compounds on that parameter. All the animal groups displayed a similar speed in the water maze, and the speed displayed on day 6 is shown in Fig. 2D. In agreement with these results no differences in the distance travelled by mice treated for 3.5 months were observed, and the number of rearings (vertical activity) were neither significantly different, although the compounds under study tended to increase the vertical activity, a measure of exploration in a novel environment. In summary, NP137 is able to counteract both the learning and memory deficits shown by TgAPP mice following prolonged administration.

As shown in Fig. 2G, AChE enzymatic activity was similar across all the experimental, in accordance with the absence of effect of the new compounds in in vitro experiments $[5]$.

\section{Activation of $\mathrm{CB}$ receptors normalized the response of AD lymphoblasts to serum stimulation or withdrawal.}

Since NP137 improved learning memory deficit in a murine model of AD, we considered interesting to evaluate the effects of this compound on the survival/death fate of human 
immortalized lymphocytes from $\mathrm{AD}$ patients in response to serum stimulation or deprivation.

Previous work from this laboratory demonstrated that $\mathrm{AD}$ lymphoblasts present neoplastic-like features, enhanced cell proliferation in the presence of serum, and increased resistance to cell death induce by serum deprivation. Moreover, it was shown that the cell responses to serum stimulation or withdrawal of AD lymphoblasts are not dependent on disease severity, as we did not observed differences between cells derived from mild, moderate or severe $\mathrm{AD}$ patients [36,37]. Therefore, experiments were performed with cell lines randomly selected from control individuals and from the three groups of AD patients. Data in Fig. 3 show, as expected, enhanced proliferation of AD lymphoblasts in the presence of serum, as well as increased resistance to serum deprivation-induced cell death in comparison with lymphoblasts derived from control, non-demented individuals [38]. The addition of NP137 $(5 \mu \mathrm{M})$ blunted the increased proliferative activity of $\mathrm{AD}$ cells, without affecting the rate of proliferation of control cells (Fig. 3). On the other hand, the presence of NP137 restored the normal cellular response to serum withdrawal, observing similar values of dying cells in both control and AD cultures $72 \mathrm{~h}$ after NP137 addition (Fig. 3). In agreement with the fact that NP137 did not affect the rate of proliferation of control cells, suggesting that NP137 does not have cytotoxic effects, we did not observe morphological changes in control or AD lymphoblasts after NP137 treatment (Fig. 4A), Moreover, we did not find significant changes in the proportion of sub-G0/G1 hypodiploid cells, characteristic of apoptosis/necrosis, in control and AD lymphoblasts in response to NP137 addition under proliferative conditions (Fig. 4B).

Overactivation of PI3K/Akt leading to decreased levels of the CDK inhibitor p27 is a distinct feature of immortalized lymphocytes from AD patients [39] accounting for the 
increased proliferative activity. For this reason, we have analyzed the effects of NP137 on PI3K/Akt activity and in the cellular content of p27. Cells were preincubated for 30 min in the presence of NP137 before serum stimulation PI3K/AKT activity was determined by assessing the levels of Akt phosphorylation with a phospho-specific antiAkt antibody, $24 \mathrm{~h}$ after serum addition. As shown in Fig. 4, NP137 prevents the increase in Akt phosphorylation in AD cells, without affecting the phosphorylation status of Akt in control cells. This effect of NP137 was accompanied by the restoration of the p27 levels in $\mathrm{AD}$ lymphoblasts to similar values observed in control cells (Fig. 2). As expected, reciprocal changes between levels of p27 and phosphorylation status of pRb protein were found (Fig. 5).

\section{NP137 restored normal ERK1/2 activity and p21 levels in AD cells under serum}

\section{deprivation}

The higher resistance of AD lymphoblasts to death induced by serum deprivation was associated with a lower sustained stimulation of ERK1/2 activity and with elevated levels of the p21 protein $[38,39]$. Fig. 6 shows that indeed, ERK1/2 activity, as monitored by the enhanced phosphorylation of ERK1/2, is severely reduced in AD cells, and in parallel p21 levels are higher. The addition of NP137 normalized both the phosphorylation status of ERK1/2 and p27 content of AD lymphoblasts (Fig. 6).

\section{Effects of NP137 on subcellular localization of p21}

It was reported previously that the protein p21 exert different nuclear and cytosolic functions [40,41]. The antiapoptotic effect of increased levels of p21 in AD lymphoblasts was associated with a shift of p21 from nucleus to the cytosolic compartment [39]. On these grounds, we decided to explore the effect of NP137 in the subcellular localization of p21 in control and AD lymphoblasts by performing nuclear and cytoplasmic fractionation experiments. Fig. 7 shows that p21 is accumulated in the cytoplasm rather 
than in nucleus in serum-deprived lymphoblasts. AD cells show a significant increase in p21 cytosolic levels, that was reduced by the presence of NP137. 


\section{Discussion}

Multitarget cannabinoids had been considered a promising therapeutic strategy for AD treatment. Here we report that NP137, and NP148, two in-house designed multitarget CB agonists showing BACE-1 and/or BuChE activities, showed neuroprotective actions against A $\beta$-induced cell death in primary rat cortical neurons and in particular NP137 improved cognitive performance in TgAPP transgenic mice. In addition, NP137 normalized the response of human $\mathrm{AD}$ lynphoblasts to serum stimulation or deprivation. Both NP137 and NP148 were able to partially prevent the cell death induced by A $\beta$ in primary rat cortical neuronal cultures. These results are in consonance with previous work showing similar neuroprotective effect of other CB2 agonist [36].

These promising results encouraged performing studies in a murine model of AD with both compounds. The compounds under study differentially affected the cognitive impairment of TgAPP mice after their continuous administration for 3 and a half months. NP137, but not NP148, was able to prevent the learning deficit in a spatial navigation task. Indeed, the enhanced latency to find the platform of TgAPP mice (vehicle treated) was counteracted by prolonged oral administration of the drug. Moreover, there was a significant recovery of the AD mice memory by NP137, as judged by the increased time spent in the target quadrant compared to TgAPP vehicle treated. These results are in line with previous reports showing amelioration of the learning and memory deficits by chronic cannabinoid agonist administration in AD models [19,20,42]. However, in WT mice we noticed a delay in their learning abilities, although at the end of the training period all animals learned the task. Previously a deleterious effect of cannabinoids had been observed in young mice following continuous administration of a low dose of $\Delta^{9}$ tetra-hydro-cannabinol, while mature or aged animals showed beneficial effects [43]. Interestingly, hippocampal gene expression changes paralleled those effects. 
Furthermore, we recently reported that fatty acid amide hydrolase activity was similarly reduced in aged rat synaptic endings and human $\mathrm{AD}$ brains, but $\mathrm{CB} 1 / \mathrm{CB} 2$ agonists reduced availability of anandamide in AD while they increased it in aging [14].

It is well known that $\mathrm{CB} 1$ and $\mathrm{CB} 1 / \mathrm{CB} 2$ mixed agonists acute administration reduces motor activity $[44,45]$, both horizontal and vertical activity, and it is considered a detrimental effect. However, upon repeated administration of such cannabinoids, tolerance develops and the hypomotor effect disappears [46]. Tolerance likely accounts for the absence of a significant effect of prolonged administration of either NP137 or NP148 on motor activity.

Several works have reported that $\mathrm{AChE}$ and $\mathrm{BuChE}$ inhibitors are able to restore the cognitive deficits shown in different models relevant to AD [47-49]. Interestingly, the beneficial effects on cognition are highly dependent on the dose, detrimental effects being observed with higher doses $[50,47]$. This fact has been attributed to high levels of ACh, which might act on the autoreceptors inhibiting its synthesis and release in the presynaptic neurons, subsequently impeding the acquisition of information. Therefore, it could be argued that the inability of NP148 that shares a similar cannabinoid agonist profile with NP137 [5], in restoring the cognitive deficits of TgAPP is related to its in vitro potency in inhibiting BuChE activity. In any case, BACE-1 inhibition, by decreasing $\mathrm{A} \beta$ generation and neuroinflammation in vivo, could contribute to the beneficial effects of NP137 [51].

Immortalized lymphocytes from $\mathrm{AD}$ and other neurodegenerative disorders have proven to be a suitable human cell-based platform to evaluate at preclinical level the potential of drug candidates for the treatment of these disorders. We evaluated the effects of NP137 in the cellular response to serum. It is assumed that cell cycle alterations in non-neuronal cells from AD patients are systemic manifestation of the disease, as aberrant cell cycle 
entry is observed in affected neurons in AD brains [52]. Our results indicate that NP137 was effective in preventing the enhanced serum stimulation of cell proliferation observed in lymphoblasts from AD patients. NP137 counteracted the overactivation of PI3K/Akt, resulting in down regulation of the $\mathrm{CDK}$ inhibitor p27 levels and subsequent recovering of normal levels of phosphorylated $\mathrm{pRb}$ protein. These findings are in consonance with previous work from our laboratory [36] in which the effects of a CB2 agonist/BuChE inhibitor was studied. Together these results support a predominant role of CB receptor activation, rather than $\mathrm{BACE}-1$, or $\mathrm{BuChE}$ activities in peripheral cells.

It was previously reported that lymphoblasts from $\mathrm{AD}$ patients showed an increased resistance to serum deprivation-induced cell death $[38,39]$. Here we show that NP137 was able to blunt the activation of the signaling cascade leading to cell death in response to serum withdrawal, namely decreased ERK1/2 activation and enhanced levels of p21, together with cytosolic accumulation of p21 [39]. These features appear to confer AD cells a survival advantage similar to that described for cancer cells [53]. In agreement with previous work showing antitumoral effects of $\mathrm{CB}$ receptor activation in $\mathrm{C} 6$ glioma cells by up-regulation of ERK1/2 activity [54], our results indicate that NP137 addition restored ERK1/2 phosphorylation levels and activity, decreased up-regulated p21 levels, and normalize p21 subcellular localization, thus sensitizing AD cells to apoptosis.

Together, our results indicate that $\mathrm{CB}$ receptor activation modulates the functional relationship PI3K/Akt or ERKs activities in serum-induced signaling in immortalized lymphocytes, controlling cell fate (proliferation/death or survival) depending on growth factor availability. The proposed scenario is represented schematically in Fig. 8.

In summary, our work revealed that the dual $\mathrm{CB}$ agonist and potent $\mathrm{BACE}-1$ inhibitor, NP137, has the capacity to restore abnormal features of AD lymphoblasts. Moreover, NP137 showed neuroprotective effects in primary rat neuronal cultures, and rescued the 
cognitive deficit of TgAPP mice. We, therefore, believe that NP137 could be a promising candidate for $\mathrm{AD}$ treatment. 


\section{Acknowledgments}

This work has been supported by grants from Ministerio de Economía y Competitividad (CTQ2015-66313-R, and RTI2018-096100-B-I00) and CIBERNED to MLC. We thank G. Porras for technical assistance. The help of Sonia Diaz Pacheco in the management and treatment of Tg APP mice is acknowledged.

\section{Authorship Contributions}

EN, PGN, FB, CA, AR, CP, MLC, JAP, NEC, AMR

Participated in research design: JAP, MLC, NEC and A M-R

Conducted experiments: EN-B, PGN, AR, CP, FB, CA, and MLC

Contributed new cannabinoids: JAP, PGN

Performed data analysis: All authors contributed to data analysis

Wrote or contributed to the writing of the manuscript: MLC, NEC, and AM-R.

\section{DISCLOSURE}

None of the authors has any conflict to disclose 


\section{References}

1. Iqbal K, Grundke-Iqbal I (2010) Alzheimer's disease, a multifactorial disorder seeking multitherapies. Alzheimers Dement 6 (5):420-424. doi:10.1016/j.jalz.2010.04.006

2. Herrup K, Neve R, Ackerman SL, Copani A (2004) Divide and die: cell cycle events as triggers of nerve cell death. J Neurosci 24 (42):9232-9239. doi:10.1523/JNEUROSCI.3347-04.2004

3. Cooper C, Mukadam N, Katona C, Lyketsos CG, Ames D, Rabins P, Engedal K, de Mendonca Lima C, Blazer D, Teri L, Brodaty H, Livingston G, World Federation of Biological Psychiatry - Old Age T (2012) Systematic review of the effectiveness of non-pharmacological interventions to improve quality of life of people with dementia. Int Psychogeriatr 24 (6):856-870. doi:10.1017/S1041610211002614

4. Gonzalez-Naranjo P, Perez-Macias N, Campillo NE, Perez C, Aran VJ, Giron R, Sanchez-Robles E, Martin MI, Gomez-Canas M, Garcia-Arencibia M, FernandezRuiz J, Paez JA (2014) Cannabinoid agonists showing BuChE inhibition as potential therapeutic agents for Alzheimer's disease. Eur J Med Chem 73:56-72. doi:10.1016/j.ejmech.2013.11.026

5. Gonzalez-Naranjo P, Perez-Macias N, Perez C, Roca C, Vaca G, Giron R, SanchezRobles E, Martin-Fontelles MI, de Ceballos ML, Martin-Requero A, Campillo NE, Paez JA (2019) Indazolylketones as new multitarget cannabinoid drugs. Eur J Med Chem 166:90-107. doi:10.1016/j.ejmech.2019.01.030

6. Gonzalez-Naranjo P, Campillo NE, Perez C, Paez JA (2013) Multitarget cannabinoids as novel strategy for Alzheimer disease. Curr Alzheimer Res 10 (3):229-239 
7. Herkenham M, Lynn AB, Little MD, Johnson MR, Melvin LS, de Costa BR, Rice KC (1990) Cannabinoid receptor localization in brain. Proc Natl Acad Sci U S A 87 (5):1932-1936

8. Munro S, Thomas KL, Abu-Shaar M (1993) Molecular characterization of a peripheral receptor for cannabinoids. Nature 365 (6441):61-65. doi:10.1038/365061a0

9. Onaivi ES, Ishiguro H, Gong JP, Patel S, Perchuk A, Meozzi PA, Myers L, Mora Z, Tagliaferro P, Gardner E, Brusco A, Akinshola BE, Liu QR, Hope B, Iwasaki S, Arinami T, Teasenfitz L, Uhl GR (2006) Discovery of the presence and functional expression of cannabinoid CB2 receptors in brain. Ann N Y Acad Sci 1074:514-536. doi:10.1196/annals.1369.052

10. den Boon FS, Chameau P, Schaafsma-Zhao Q, van Aken W, Bari M, Oddi S, Kruse CG, Maccarrone M, Wadman WJ, Werkman TR (2012) Excitability of prefrontal cortical pyramidal neurons is modulated by activation of intracellular type-2 cannabinoid receptors. Proc Natl Acad Sci U S A 109 (9):3534-3539. doi:10.1073/pnas.1118167109

11. Paez JA, Campillo NE (2018) Innovative Therapeutic Potential of Cannabinoid Receptors as Targets in Alzheimer's disease and Less Well-Known Diseases. Curr Med Chem. doi:10.2174/0929867325666180226095132

12. Ramirez BG, Blazquez C, Gomez del Pulgar T, Guzman M, de Ceballos ML (2005) Prevention of Alzheimer's disease pathology by cannabinoids: neuroprotection mediated by blockade of microglial activation. J Neurosci 25 (8):1904-1913. doi:10.1523/JNEUROSCI.4540-04.2005

13. Mulder J, Zilberter M, Pasquare SJ, Alpar A, Schulte G, Ferreira SG, Kofalvi A, Martin-Moreno AM, Keimpema E, Tanila H, Watanabe M, Mackie K, Hortobagyi T, de Ceballos ML, Harkany T (2011) Molecular reorganization of endocannabinoid 
signalling in Alzheimer's disease. Brain $134 \quad(\mathrm{Pt} \quad 4): 1041-1060$. doi:10.1093/brain/awr046

14. Pascual AC, Martin-Moreno AM, Giusto NM, de Ceballos ML, Pasquare SJ (2014) Normal aging in rats and pathological aging in human Alzheimer's disease decrease FAAH activity: modulation by cannabinoid agonists. Exp Gerontol 60:92-99. doi:10.1016/j.exger.2014.10.011

15. Jung KM, Astarita G, Yasar S, Vasilevko V, Cribbs DH, Head E, Cotman CW, Piomelli D (2012) An amyloid beta42-dependent deficit in anandamide mobilization is associated with cognitive dysfunction in Alzheimer's disease. Neurobiol Aging 33 (8):1522-1532. doi:10.1016/j.neurobiolaging.2011.03.012

16. Sun S, Hu F, Wu J, Zhang S (2017) Cannabidiol attenuates OGD/R-induced damage by enhancing mitochondrial bioenergetics and modulating glucose metabolism via pentose-phosphate pathway in hippocampal neurons. Redox Biol 11:577-585. doi:10.1016/j.redox.2016.12.029

17. Zhuang Q, Dai C, Yang L, Wen H, Wang H, Jiang X, Zhang Y (2017) Stimulated CB1 Cannabinoid Receptor Inducing Ischemic Tolerance and Protecting Neuron from Cerebral Ischemia. Cent Nerv Syst Agents Med Chem 17 (2):141-150. doi:10.2174/1871524916666160504104624

18. Campillo NE, Paez JA (2009) Cannabinoid system in neurodegeneration: new perspectives in Alzheimer's disease. Mini Rev Med Chem 9 (5):539-559

19. Martin-Moreno AM, Brera B, Spuch C, Carro E, Garcia-Garcia L, Delgado M, Pozo MA, Innamorato NG, Cuadrado A, de Ceballos ML (2012) Prolonged oral cannabinoid administration prevents neuroinflammation, lowers beta-amyloid levels and improves cognitive performance in Tg APP 2576 mice. J Neuroinflammation 9:8. doi:10.1186/1742-2094-9-8 
20. Martin-Moreno AM, Reigada D, Ramirez BG, Mechoulam R, Innamorato N, Cuadrado A, de Ceballos ML (2011) Cannabidiol and other cannabinoids reduce microglial activation in vitro and in vivo: relevance to Alzheimer's disease. Mol Pharmacol 79 (6):964-973. doi:10.1124/mol.111.071290

21. Holsinger RM, McLean CA, Beyreuther K, Masters CL, Evin G (2002) Increased expression of the amyloid precursor beta-secretase in Alzheimer's disease. Ann Neurol 51 (6):783-786. doi:10.1002/ana.10208

22. Yang LB, Lindholm K, Yan R, Citron M, Xia W, Yang XL, Beach T, Sue L, Wong P, Price D, Li R, Shen Y (2003) Elevated beta-secretase expression and enzymatic activity detected in sporadic Alzheimer disease. Nat Med 9 (1):3-4. doi:10.1038/nm0103-3

23. Yue X, Lu M, Lancaster T, Cao P, Honda S, Staufenbiel M, Harada N, Zhong Z, Shen Y, Li R (2005) Brain estrogen deficiency accelerates Abeta plaque formation in an Alzheimer's disease animal model. Proc Natl Acad Sci U S A 102 (52):19198-19203. doi:10.1073/pnas.0505203102

24. Zohar O, Pick CG, Cavallaro S, Chapman J, Katzav A, Milman A, Alkon DL (2005) Age-dependent differential expression of BACE splice variants in brain regions of $\begin{array}{lllll}\operatorname{tg} 2576 & \text { mice. } & \text { Neurobiol } & \end{array}$ doi:10.1016/j.neurobiolaging.2004.10.005

25. Mushtaq G, Greig NH, Khan JA, Kamal MA (2014) Status of acetylcholinesterase and butyrylcholinesterase in Alzheimer's disease and type 2 diabetes mellitus. CNS Neurol Disord Drug Targets 13 (8):1432-1439

26. Li B, Stribley JA, Ticu A, Xie W, Schopfer LM, Hammond P, Brimijoin S, Hinrichs SH, Lockridge O (2000) Abundant tissue butyrylcholinesterase and its possible function in the acetylcholinesterase knockout mouse. J Neurochem 75 (3):1320-1331 
27. Mesulam MM, Geula C (1994) Butyrylcholinesterase reactivity differentiates the amyloid plaques of aging from those of dementia. Ann Neurol 36 (5):722-727. doi:10.1002/ana.410360506

28. Mesulam MM, Guillozet A, Shaw P, Levey A, Duysen EG, Lockridge O (2002) Acetylcholinesterase knockouts establish central cholinergic pathways and can use butyrylcholinesterase to hydrolyze acetylcholine. Neuroscience 110 (4):627-639

29. Darvesh S, Hopkins DA, Geula C (2003) Neurobiology of butyrylcholinesterase. Nat Rev Neurosci 4 (2):131-138. doi:10.1038/nrn1035

30. Pruszak J, Just L, Isacson O, Nikkhah G (2009) Isolation and culture of ventral mesencephalic precursor cells and dopaminergic neurons from rodent brains. Curr Protoc Stem Cell Biol Chapter 2:Unit 2D 5. doi:10.1002/9780470151808.sc02d05s11

31. Yin LH, Shen H, Diaz-Ruiz O, Backman CM, Bae E, Yu SJ, Wang Y (2012) Early post-treatment with 9-cis retinoic acid reduces neurodegeneration of dopaminergic neurons in a rat model of Parkinson's disease. BMC Neurosci 13:120. doi:10.1186/1471-2202-13-120

32. Denizot F, Lang R (1986) Rapid colorimetric assay for cell growth and survival. Modifications to the tetrazolium dye procedure giving improved sensitivity and reliability. J Immunol Methods 89 (2):271-277

33. Ibarreta D, Parrilla R, Ayuso MS (1997) Altered Ca2+ homeostasis in lymphoblasts from patients with late-onset Alzheimer disease. Alzheimer Dis Assoc Disord 11 (4):220-227

34. Alquezar C, Esteras N, de la Encarnacion A, Alzualde A, Moreno F, Lopez de Munain A, Martin-Requero A (2014) PGRN haploinsufficiency increased Wnt5a signaling in peripheral cells from frontotemporal lobar degeneration-progranulin mutation carriers. Neurobiol Aging 35 (4):886-898. doi:10.1016/j.neurobiolaging.2013.09.021 
35. Esteras N, Alquezar C, Bartolome F, de la Encarnacion A, Bermejo-Pareja F, Molina JA, Martin-Requero A (2015) G1/S Cell Cycle Checkpoint Dysfunction in Lymphoblasts from Sporadic Parkinson's Disease Patients. Mol Neurobiol 52 (1):386398. doi:10.1007/s12035-014-8870-y

36. Del Cerro P, Alquezar C, Bartolome F, Gonzalez-Naranjo P, Perez C, Carro E, Paez JA, Campillo NE, Martin-Requero A (2018) Activation of the Cannabinoid Type 2 Receptor by a Novel Indazole Derivative Normalizes the Survival Pattern of Lymphoblasts from Patients with Late-Onset Alzheimer's Disease. CNS Drugs 32 (6):579-591. doi:10.1007/s40263-018-0515-7

37. Esteras N, Alquezar C, Bermejo-Pareja F, Bialopiotrowicz E, Wojda U, MartinRequero A (2013) Downregulation of extracellular signal-regulated kinase 1/2 activity by calmodulin KII modulates p21Cip1 levels and survival of immortalized lymphocytes from Alzheimer's disease patients. Neurobiol Aging 34 (4):1090-1100. doi:10.1016/j.neurobiolaging.2012.10.014

38. Bartolome F, de Las Cuevas N, Munoz U, Bermejo F, Martin-Requero A (2007) Impaired apoptosis in lymphoblasts from Alzheimer's disease patients: cross-talk of Ca2+/calmodulin and ERK1/2 signaling pathways. Cell Mol Life Sci 64 (11):14371448. doi:10.1007/s00018-007-7081-3

39. Munoz U, Bartolome F, Bermejo F, Martin-Requero A (2008) Enhanced proteasomedependent degradation of the CDK inhibitor p27(kip1) in immortalized lymphocytes from Alzheimer's dementia patients. Neurobiol Aging 29 (10):1474-1484. doi:10.1016/j.neurobiolaging.2007.03.013

40. Agell N, Jaumot M, Rodriguez-Vilarrupla A, Brun S, Abella N, Canela N, Estanyol JM, Bachs O (2006) The diverging roles of calmodulin and PKC in the regulation of p21 intracellular localization. Cell Cycle 5 (1):3-6. doi:10.4161/cc.5.1.2270 
41. Coqueret O (2003) New roles for p21 and p27 cell-cycle inhibitors: a function for each cell compartment? Trends Cell Biol 13 (2):65-70

42. Aso E, Ferrer I (2014) Cannabinoids for treatment of Alzheimer's disease: moving toward the clinic. Front Pharmacol 5:37. doi:10.3389/fphar.2014.00037

43. Bilkei-Gorzo A, Albayram O, Draffehn A, Michel K, Piyanova A, Oppenheimer H, Dvir-Ginzberg M, Racz I, Ulas T, Imbeault S, Bab I, Schultze JL, Zimmer A (2017) A chronic low dose of Delta(9)-tetrahydrocannabinol (THC) restores cognitive function in old mice. Nat Med 23 (6):782-787. doi:10.1038/nm.4311

44. Wiley JL, Martin BR (2003) Cannabinoid pharmacological properties common to other centrally acting drugs. Eur J Pharmacol 471 (3):185-193

45. Jarbe TU, Ross T, DiPatrizio NV, Pandarinathan L, Makriyannis A (2006) Effects of the CB1R agonist WIN-55,212-2 and the CB1R antagonists SR-141716 and AM1387: open-field examination in rats. Pharmacol Biochem Behav 85 (1):243-252. doi:10.1016/j.pbb.2006.08.006

46. Hampson RE, Simeral JD, Kelly EJ, Deadwyler SA (2003) Tolerance to the memory disruptive effects of cannabinoids involves adaptation by hippocampal neurons. Hippocampus 13 (5):543-556. doi:10.1002/hipo.10081

47. Van Dam D, Marescau B, Engelborghs S, Cremers T, Mulder J, Staufenbiel M, De Deyn PP (2005) Analysis of cholinergic markers, biogenic amines, and amino acids in the CNS of two APP overexpression mouse models. Neurochem Int 46 (5):409-422. doi:10.1016/j.neuint.2004.11.005

48. Lian W, Fang J, Xu L, Zhou W, Kang, Xiong W, Jia H, Liu AL, Du GH (2017) DL0410 Ameliorates Memory and Cognitive Impairments Induced by Scopolamine via Increasing Cholinergic Neurotransmission in Mice. Molecules 22 (3). doi:10.3390/molecules22030410 
49. Wang X, Li P, Ding Q, Wu C, Zhang W, Tang B (2019) Observation of Acetylcholinesterase in Stress-Induced Depression Phenotypes by Two-Photon Fluorescence Imaging in the Mouse Brain. J Am Chem Soc 141 (5):2061-2068. doi: $10.1021 /$ jacs. 8 b1 1414

50. Bejar C, Wang RH, Weinstock M (1999) Effect of rivastigmine on scopolamineinduced memory impairment in rats. Eur J Pharmacol 383 (3):231-240

51. Neumann U, Rueeger H, Machauer R, Veenstra SJ, Lueoend RM, Tintelnot-Blomley M, Laue G, Beltz K, Vogg B, Schmid P, Frieauff W, Shimshek DR, Staufenbiel M, Jacobson LH (2015) A novel BACE inhibitor NB-360 shows a superior pharmacological profile and robust reduction of amyloid-beta and neuroinflammation in APP transgenic mice. Mol Neurodegener 10:44. doi:10.1186/s13024-015-0033-8

52. Arendt T (2012) Cell cycle activation and aneuploid neurons in Alzheimer's disease. Mol Neurobiol 46 (1):125-135. doi:10.1007/s12035-012-8262-0

53. Weiss RH (2003) p21Waf1/Cip1 as a therapeutic target in breast and other cancers. Cancer Cell 4 (6):425-429

54. Sanchez C, de Ceballos ML, Gomez del Pulgar T, Rueda D, Corbacho C, Velasco G, Galve-Roperh I, Huffman JW, Ramon y Cajal S, Guzman M (2001) Inhibition of glioma growth in vivo by selective activation of the $\mathrm{CB}(2)$ cannabinoid receptor. Cancer Res 61 (15):5784-5789

55. Ponzoni I, Sebastian-Perez V, Requena-Triguero C, Roca C, Martinez MJ, Cravero F, Diaz MF, Paez JA, Arrayas RG, Adrio J, Campillo NE (2017) Hybridizing Feature Selection and Feature Learning Approaches in QSAR Modeling for Drug Discovery. Sci Rep 7 (1):2403. doi:10.1038/s41598-017-02114-3 


\section{Legend to the figures}

\section{Fig. 1}

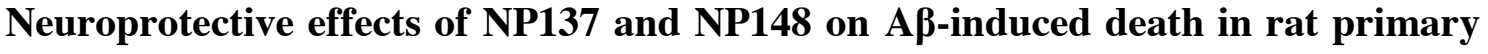 cortical neurons}

Rat cortical primary neurons were exposed to $5 \mu \mathrm{M} A \beta$ for 24 hours in the presence or in the absence of 2.5, 5 and $10 \mu \mathrm{M}$ of NP137 (left panel) or NP148 (right panel). The number of viable cells was measured by MTT assay. Each data point represents the mean \pm SEM of three replications in 5 different experiments. ${ }^{*} \mathrm{p}<0.05$ $* * * p<0.001$ significantly different from untreated cells; and $\uparrow \mathrm{p}<0.05, \dagger \dagger \mathrm{p}<0.01$, and $\dagger \dagger \uparrow \mathrm{p}<0.001$ significantly different from $\mathrm{A} \beta$-treated cells.

\section{Fig. 2.}

NP137 counteracts cognitive deficits in TgAPP mice. Following oral administration for 3.5 months starting at 12 months of age the effect of the compounds NP137 and NP148 on a spatial navigation task was assessed. Latency (sec) to reach the hidden platform in the water maze of vehicle treated (veh) or treated with NP137 and NP148 over the 5 training days. A) Effects on WT mice. NP137 delayed WT mice learning. B) Effects on TgAPP mice. NP137 counteracted TgAPP mice learning deficits. C) Time spent in the target quadrant (platform location). TgAPP (vehicle treated) mice spent less time in the target quadrant, while NP137 prevented that reduction. D) All mice showed similar speed while swimming in the water maze on the probe trial day ( $6^{\text {th }}$ day). E) All animals displayed a similar locomotor activity (distance travelled in cm over $10 \mathrm{~min}$ ) in the open field. F) Number of rears (vertical activity) were not significantly different across the different groups. G) AChE enzymatic activity in cerebral cortex samples were 
measured in triplicates. Results are expressed in $\mathrm{pmol} / \mathrm{min} \mathrm{x} \mathrm{mg}$ of tissue (wet weight). ${ }^{*} \mathrm{p}<0.05$ vs WT mice, $\# \mathrm{p}<0.05$ vs Tg APP + veh mice.

Fig. 3

\section{NP137 normalized the cell response to serum stimulation or withdrawal}

Immortalized lymphocytes from control and late-onset $\mathrm{AD}$ patients were seeded at an initial density of $1 \times 10^{6} \mathrm{x} \mathrm{ml}^{-1}$ and incubated with or without $10 \%$ FBS in the absence or in presence of NP137 $(5 \mu \mathrm{M})$. Aliquots were taken for cell counting 72 hours after the drug administration. Data shown are the mean \pm SEM for 10 observations carried out with cell lines from different individuals. ${ }^{*} p<0.05$, significantly different from control cells. $\uparrow \mathrm{p}<0.05$, significantly different from untreated AD cells.

\section{Fig. 4}

NP137 does not induce morphological alterations or apoptosis in control and AD

\section{lymphoblasts.}

Immortalized lymphocytes from control and late-onset $\mathrm{AD}$ patients were seeded at an initial density of $1 \times 10^{6} \times \mathrm{ml}^{-1}$ and incubated with $10 \%$ FBS in the absence or in the presence of NP137 (5 $5 \mathrm{M})$. A) Morphological images were taken using an inverted phase contrast Olympus microscope IX-50 with x40 objective. Images were taken with a CCD camera Hamamatsu 9100-02. Scale bar: $50 \mu \mathrm{m}$. B) Cell cycle analysis of control and AD lymphoblasts after treatment with NP137. The percentage of cells in Sub $\mathrm{G}_{1}$ is indicated for each condition.

\section{Fig. 5}

NP137 restores the phosphorylation status of Akt and pRb proteins, and cellular content of p27 in AD lymphoblasts. 
Immortalized lymphocytes from control and AD patients, were seeded at an initial density of $1 \times 10^{6} \times \mathrm{ml}^{-1}$, and incubated in RPMI medium containing $10 \%$ FBS in the absence or in the presence of the CB agonist NP137 $(5 \mu \mathrm{M})$. Cell extracts were prepared 24 hours after drug administration to determine levels of phosphorylation of Akt, p27 and pRb by Western blot using phospho-specific antibodies. Representative immunoblots are shown. The densitometric data represent the mean \pm SEM of 6-10 different experiments $* \mathrm{p}<0.05$; $* * p<0.01$ significantly different from control cells. $\uparrow p<0.05 \uparrow \uparrow p<0.01$ significantly different from untreated AD cells.

\section{Fig. 6}

NP137 increases ERK1/2 activation and p21 levels in serum-deprived AD

\section{lymphoblasts}

Immortalized lymphocytes from control and AD patients, were seeded at an initial density of $1 \times 10^{6} \mathrm{x} \mathrm{ml}^{-1}$ and incubated in serum deprived-RPMI medium in the absence or in the presence of NP137 $(5 \mu \mathrm{M})$. Cell extracts were prepared 72 hours after drug administration to determine levels of phosphorylation of ERK1/2, and cellular levels of p21 by Western blot. Representative immunoblots are shown. The densitometric data represent the mean \pm SEM of 5 different experiments, ${ }^{*} \mathrm{p}<0.05$, significantly different from control cells. $\dagger \mathrm{p}<0.05$, significantly different from untreated AD cells.

\section{Fig. 7}

NP137 counteracts the enhanced p21 nucleo-cytoplasmic shuttling in serumdeprived AD lymphoblasts

Lymphoblasts from control and $\mathrm{AD}$ patients were seeded at an initial density of $1 \times 10^{6} \mathrm{x}$ $\mathrm{ml}^{-1}$, incubated in the absence of serum for 72 hours, and then fractionated to determine by immunoblot analysis the subcellular localization of $\mathrm{p} 21$. Antibodies to $\alpha$-tubulin and 
to lamin B1 were used as control of purity and loading of cytoplasmic and nuclear protein extracts, respectively. A representative immunoblot is shown, whereas the densitometric analysis is presented below. Data represent \pm SEM of 5 different experiments. $* * * p<0.001$, significantly different from control cells, $\uparrow \dagger \uparrow \mathrm{p}<0.001$, significantly different from untreated $\mathrm{AD}$ cells.

\section{Fig. 8}

Diagram summarizing the effects of targeting $\mathrm{CB}$ receptors on fate of $\mathrm{AD}$ lymphoblasts upon serum stimulation or withdrawal.

In the presence of serum $\mathrm{AD}$ cells show enhanced activation of PI3K/Akt leading to decreased levels of $\mathrm{p} 27$, and activation of cyclin/CDK/pRb, therefore favoring the progression of cells through the cell cycle. In the absence of serum, ERK1/2 activity is downregulated in comparison with control cells, which in turn induces an increase on the cellular content of $\mathrm{p} 21$, as well as favors the cytosolic localization of $\mathrm{p} 21$, which then seems to protect $\mathrm{AD}$ lymphoblasts from the serum deprivation-induced apoptosis. 
Table 1. Activity profile of NP137 and NP148

\begin{tabular}{|c|c|c|c|c|c|}
\hline Structure & Code & $\begin{array}{c}\mathrm{CBR}^{\mathrm{a}} \\
(\mathrm{Emax})\end{array}$ & $\begin{array}{c}\text { BACE-1 }{ }^{\mathrm{b}} \\
\text { \%Inhibition } \\
(10 \mu \mathrm{M})\end{array}$ & $\begin{array}{c}\mathrm{BuChE}^{\mathrm{c}} \\
\mathrm{IC}_{50}\end{array}$ & $\begin{array}{c}\operatorname{logBB} \\
{[55]}\end{array}$ \\
\hline & NP137 & $\begin{array}{l}\text { Agonist } \\
\text { CB1/CB2 }\end{array}$ & $60 \pm 8$ & $>10(42 \%)$ & BBB + \\
\hline & NP148 & $\begin{array}{l}\text { Agonist } \\
\text { CB1/CB2 }\end{array}$ & $38.35 \pm 1.11$ & $2.5 \pm 1.2 \mathrm{nM}$ & $\mathrm{BBB}+$ \\
\hline
\end{tabular}

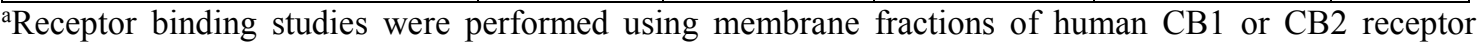
transfected cells (HEK293EBNA). ${ }^{b}$ Percentage of inhibition of BACE-1 at $10 \mu \mathrm{M}$. ${ }^{\mathrm{C}} \mathrm{IC}_{50}$ half maximal inhibitory concentration values (mean \pm standard error of the mean) were determined from three different experiments using $0.5 \mathrm{mM}$ of $\mathrm{BuChE}$ as the substrate [48]. BBB prediction was estimated as previously reported [55]. 
Table 2. Summary of the study population

\begin{tabular}{lll}
\hline & CONTROL & AD \\
\hline Age & $68 \pm 10$ & $74 \pm 6$ \\
Age range & $50-83$ & $56-82$ \\
Gender & & \\
$\quad$ Male & 8 & 11 \\
Female & 12 & 9 \\
Total & 20 & 20 \\
Control: individuals with no sign of neurological disease. AD: patients with a \\
diagnosis of probable AD. Values are expressed as means \pm SD
\end{tabular}



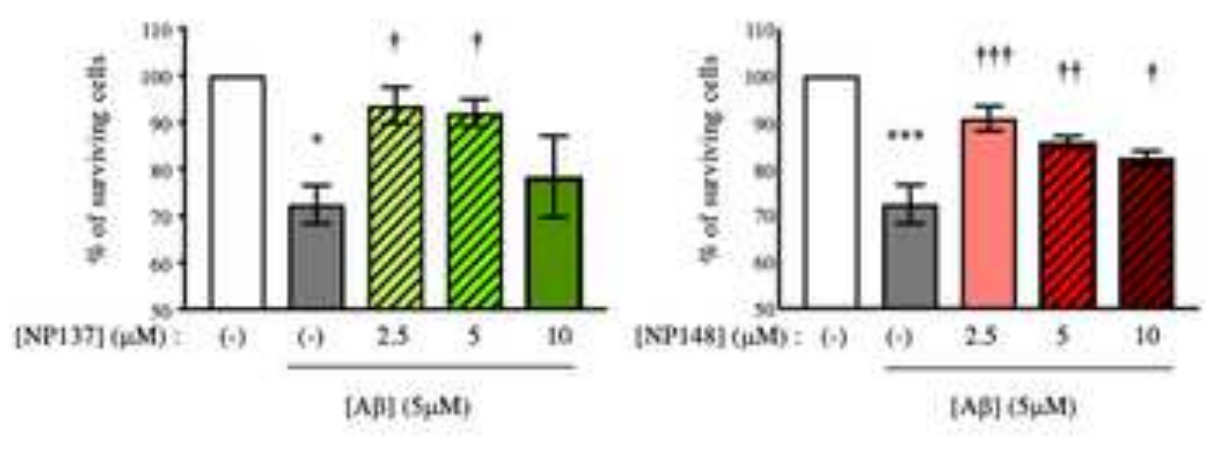

Figure I

Figure 1

(AB) 
A B

B

C
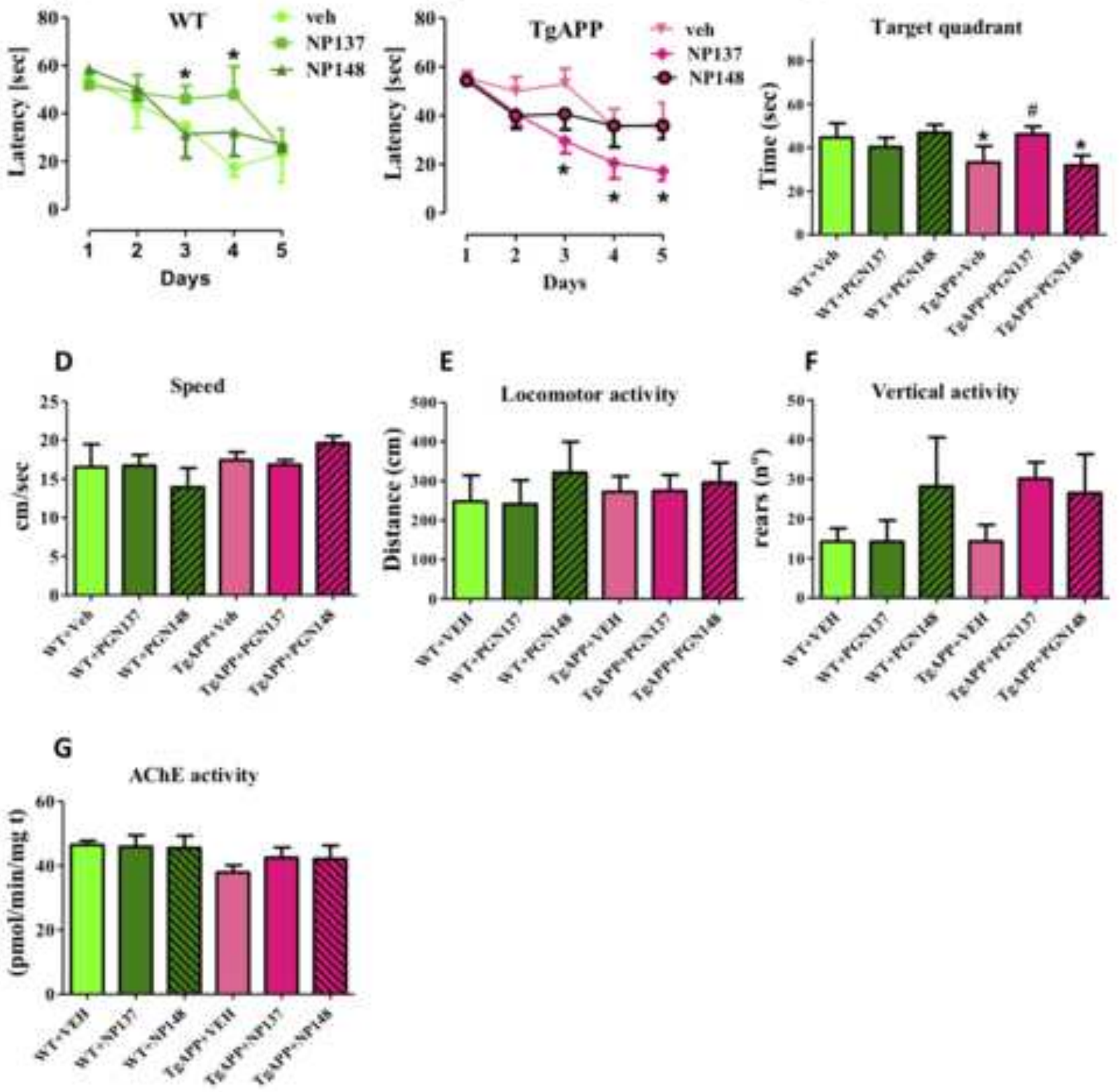

Figure.2 


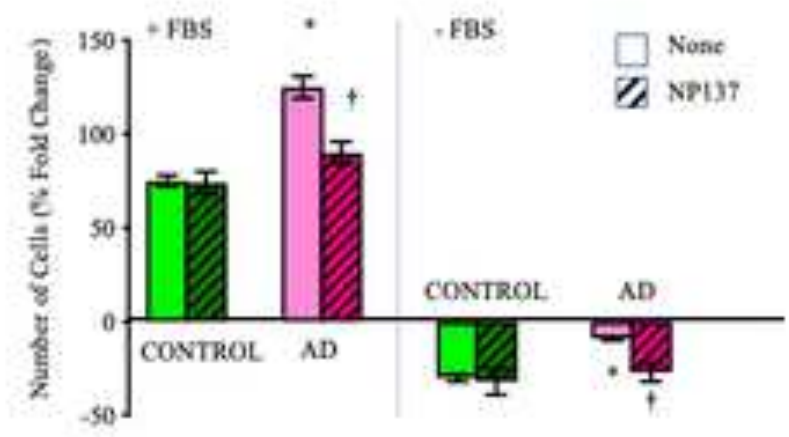

Fience 3 
A

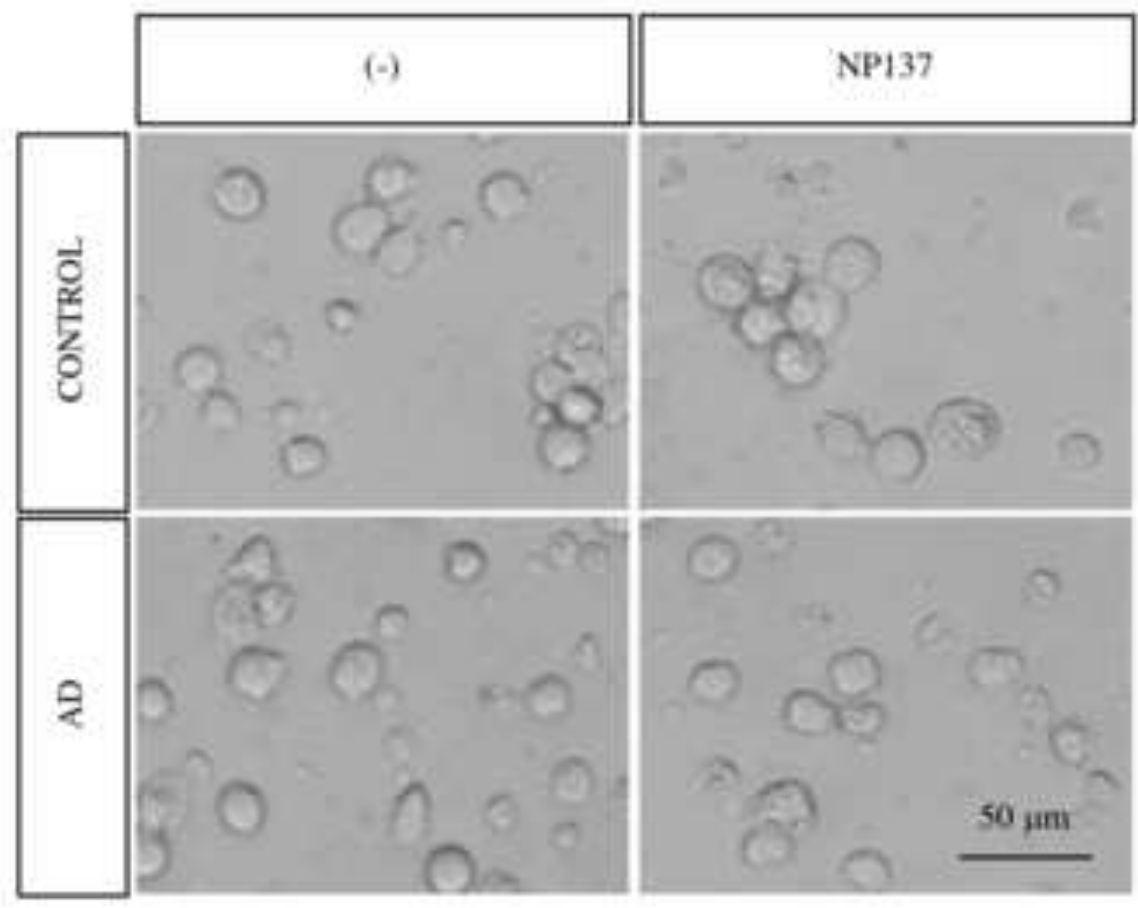

B

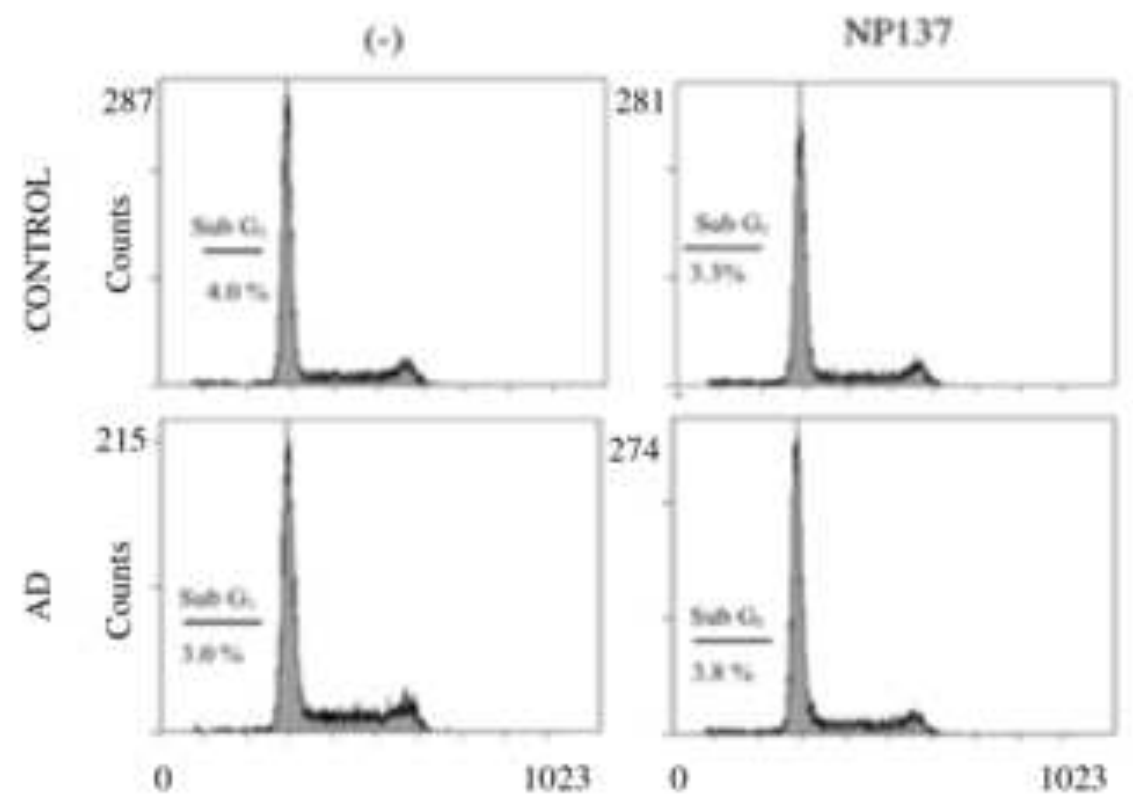

Figure 4 

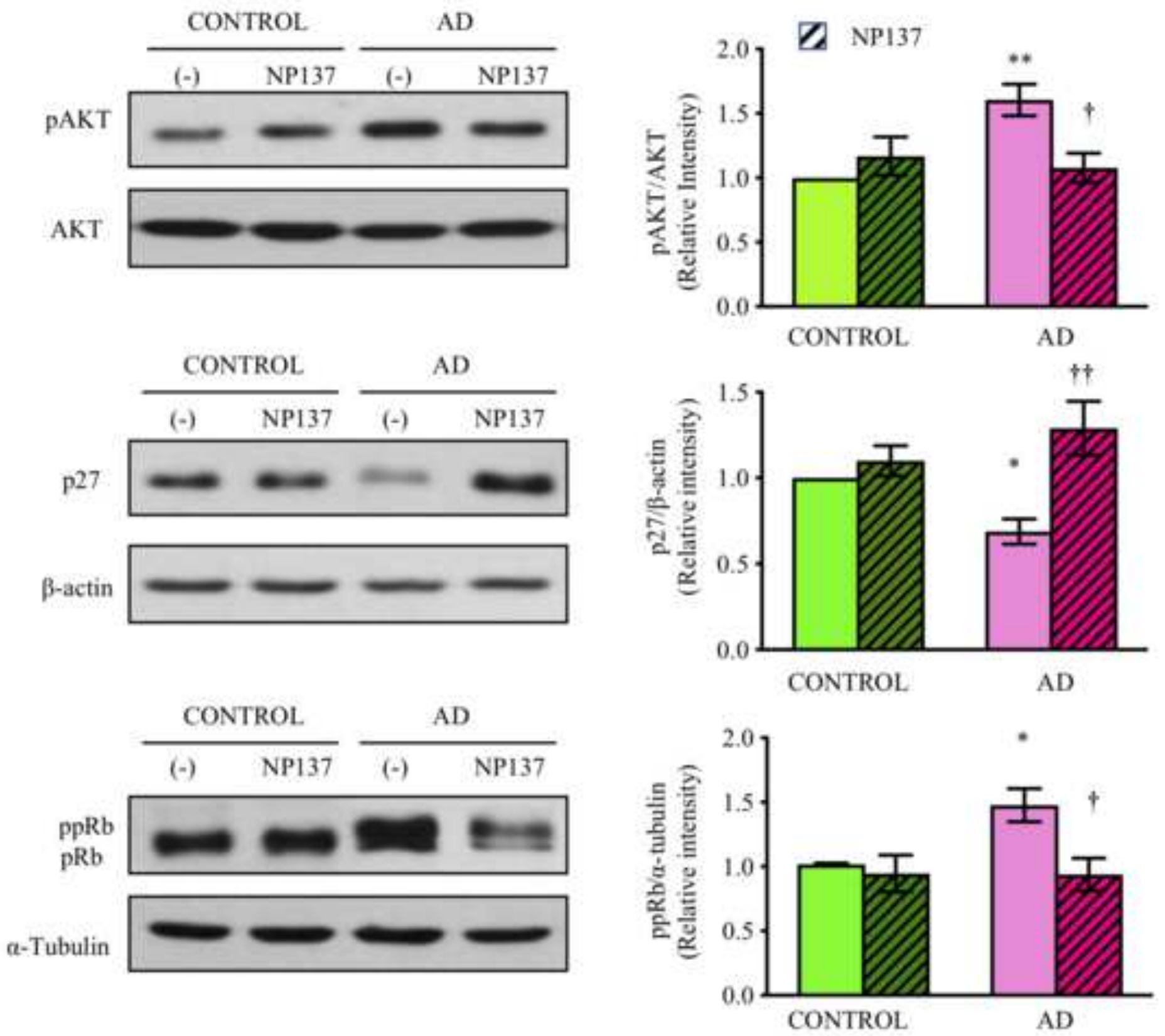

Figure 5 


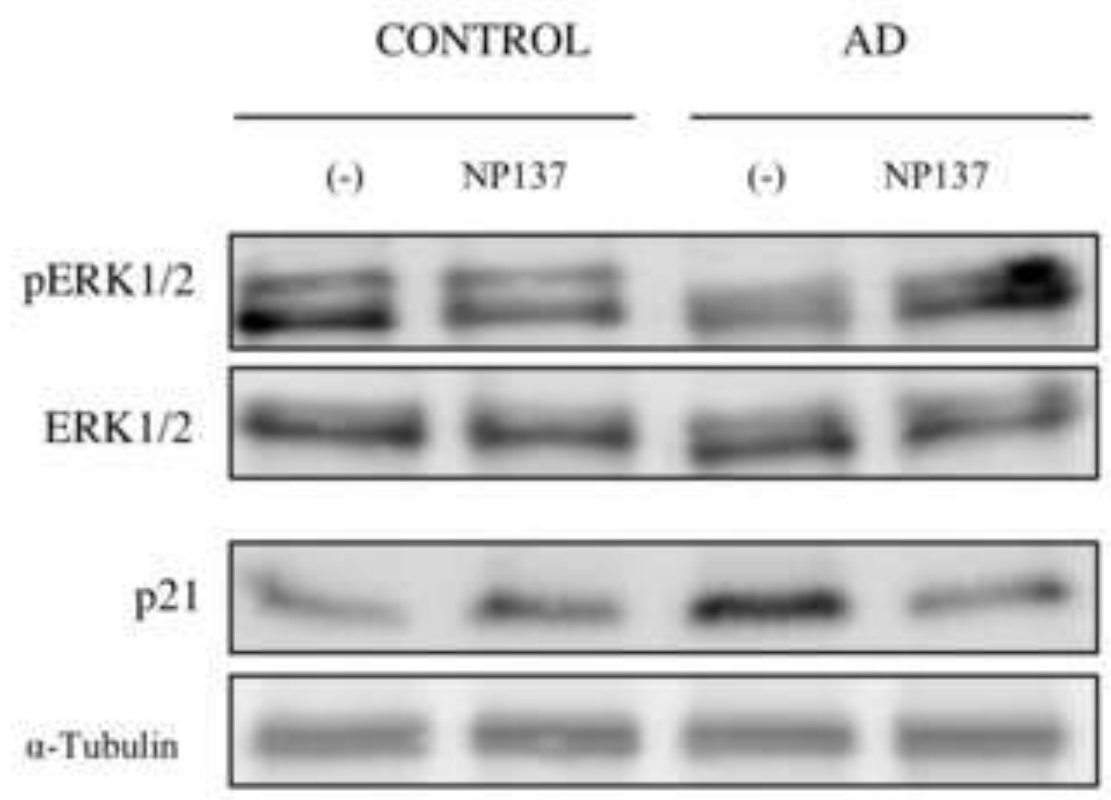

$\square$ None

(2) NP137
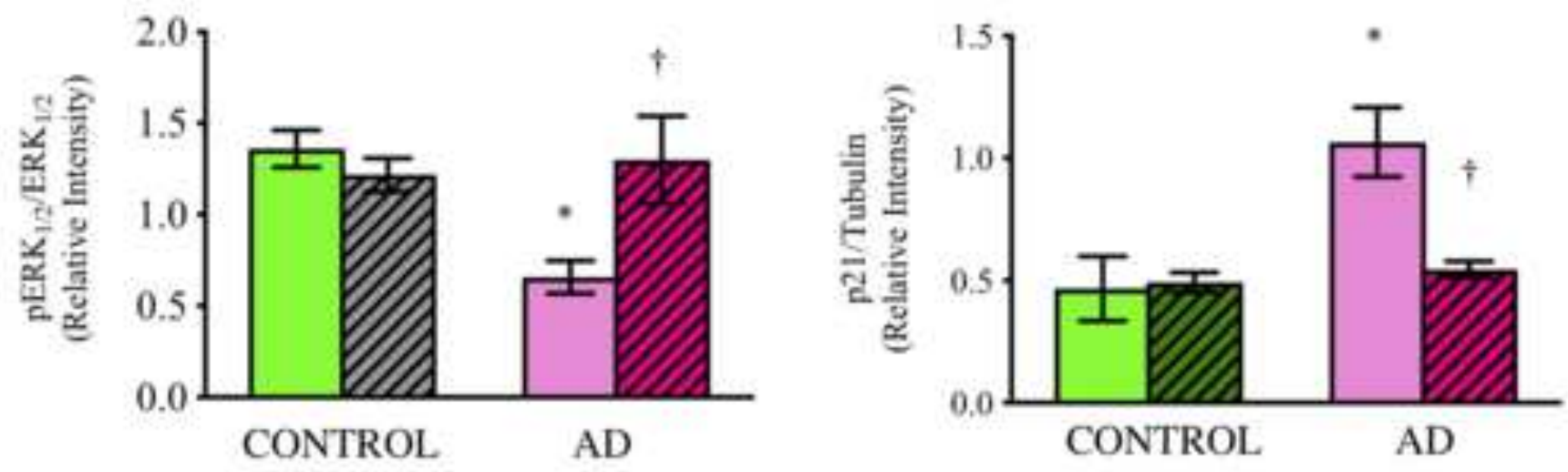

Figure 6 
CONTROL

$\begin{array}{llll}(-) & \text { NP137 } & (-) & \text { NP137 }\end{array}$

p21

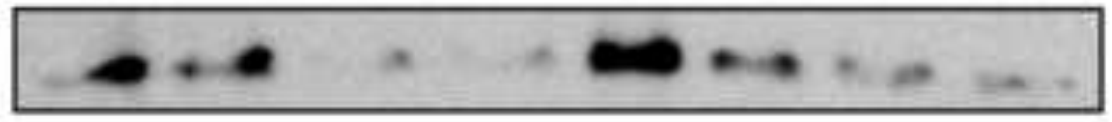

Lamin B |

$\alpha$-Tubulin

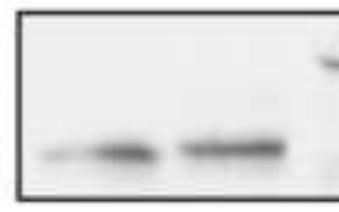

Cytosol

Nucleus

Cytosol

AD

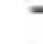
(-) NP137
(-) NP137
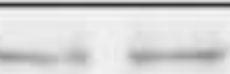

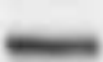
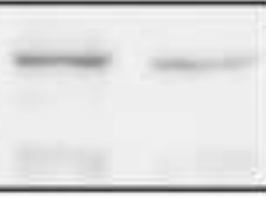

Nucleus

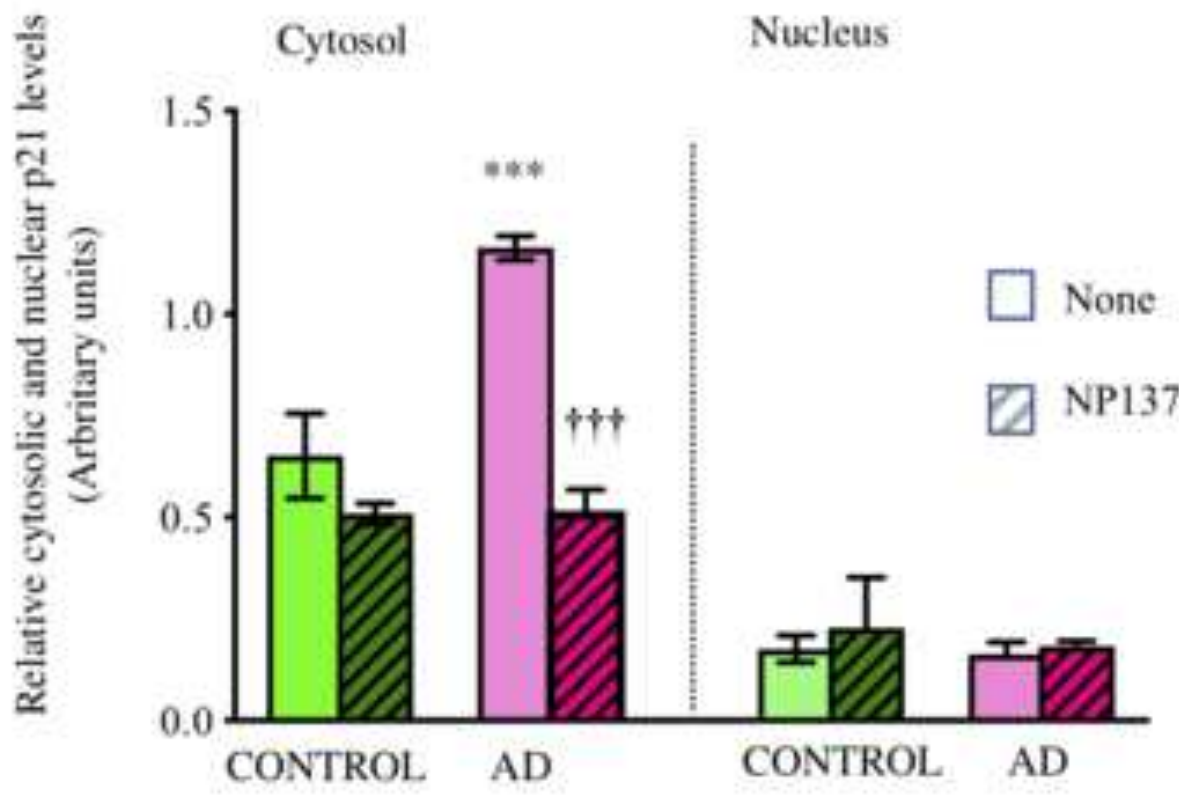

Figure 7 


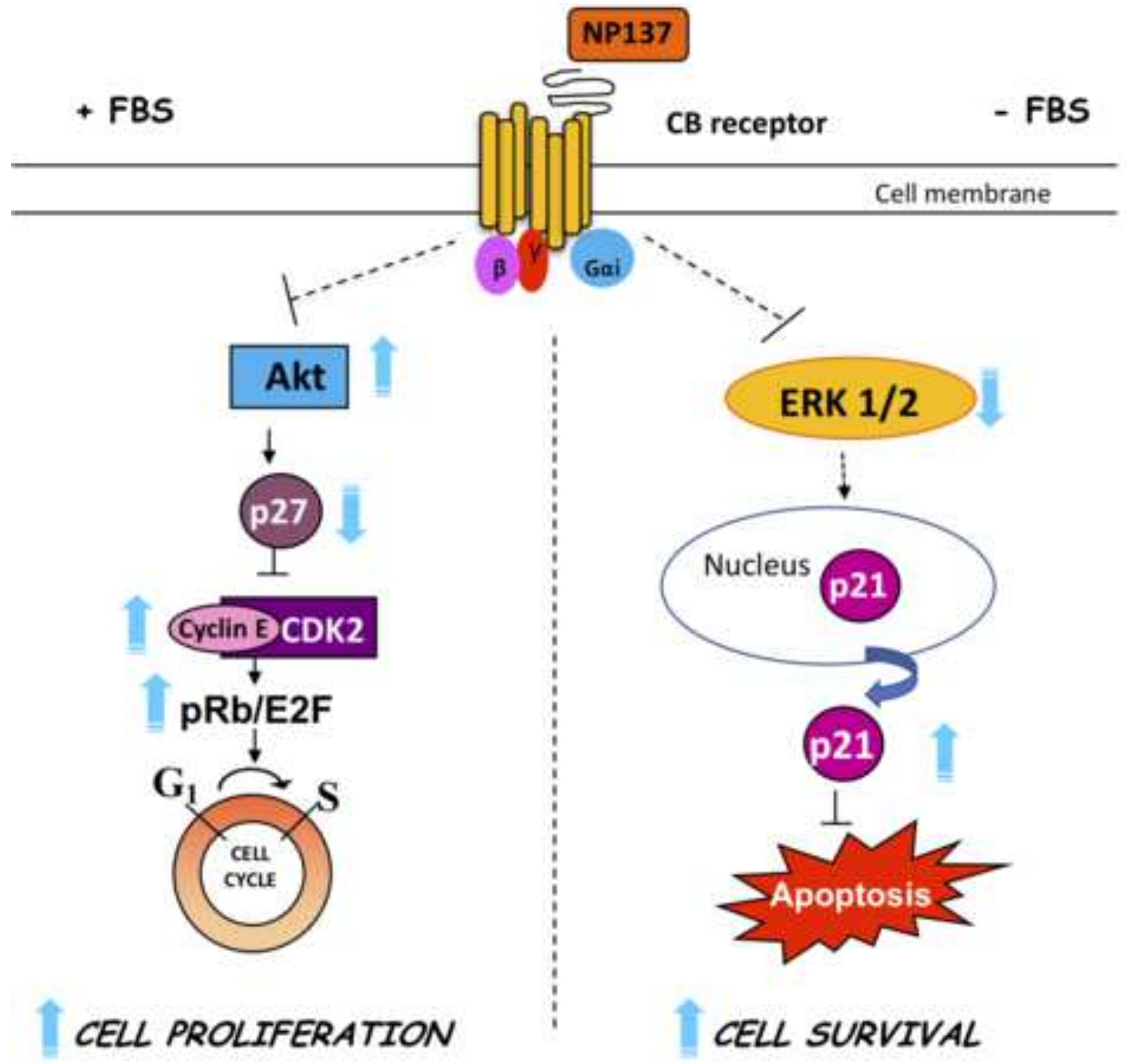

